\title{
CENTURY-SCALE SHORELINE CHANGES OF FIVE BEACHES IN JAPAN
}

\author{
Jun Yoshida ${ }^{1}$, Keiko Udo², Yuriko Takeda², and Akira MANO
}

\begin{abstract}
Coastal erosion caused by sea level rise is a serious problem for people all over the world. Global sea level will rise from 0.18 to $0.59 \mathrm{~m}$ (IPCC, 2007). Along the coasts in Japan, sea level will rise from 0.09 to $0.27 \mathrm{~m}$ by the end of this century. The future estimation considers only thermal expansion due to rising sea temperature caused by global warming. However, considering the contribution of scale-down of Greenland and Antarctic ice sheet, there is potential of the increase in the rate of sea level rise. There are few studies which evaluate impacts of the future beach erosion on society by comparing with the past shoreline change resulting from natural forces and human activities. This study evaluates the long-term shoreline changes due to natural forces and human activities by using old maps. Shoreline changes were influenced by natural forces from 1900 to 1950 and were influenced by human activities from 1950 to 1990. Shoreline changes showed that the changes tended to be stable after 1990, and coastal erosion due to climate change would likely become obvious in the future.
\end{abstract}

Keywords: beach erosion; shoreline change; old map

\section{INTRODUCTION}

There is growing concern about sea-level rise due to thermal expansion and ice sheet melt caused by global warming. Coastal erosion caused by sea-level rise is the serious problem for people all over the world. The Intergovernmental Panel on Climate Change (2007) recently estimated that global sea level will rise from 0.18 to $0.59 \mathrm{~m}$ by the end of this century .According to a future greenhouse gas emission change scenario (IPCC SRES AIB scenario) calculated by North Pacific Ocean General Circulation Model (NPOGCM), Japan Meteorological Agency (2008) estimates that sea level around Japan will rise from 0.09 to $0.27 \mathrm{~m}$, compared with that from 1981 to 2000. The future estimation considers only thermal expansion due to rising sea temperature caused by global warming. However, considering the contribution of scale-down of Greenland and Antarctic ice sheet, there is potential of the increase in the rate of sea level rise.

Change of wave characteristics due to climate change is another concern, such as the increase of wave height during storms caused by large typhoons. Mori et al. (2009) shows that mean wave height around Japan will decrease at the end of 21st century, compared with it from 1979 to 2003, and that maximum wave height will be much higher clearly.

When sea level rises and wave height is higher during storms, the risk of coastal erosion is increasing and shoreline is retreating in a long term. In Japan the population is concentrated in coastal areas, and shoreline retreat will have effects on society and economics, such as population and property. The estimation of shoreline change due to climate change is a pressing issue, because $10 \%$ of the world's population lives in low-lying coastal regions within $10 \mathrm{~m}$ above the present sea level (McGranahan et al. 2007).

Several studies show that sea level rise is responsible for long-term beach erosion (Zhang et al., 2004). Future shoreline change has been estimated by many researchers using Bruun rule (Mimura et al., 1994; Ranasinghe and Stive 2009). Mimura et al. (1994) predicted coastal erosion in each Japanese prefecture. Sugawa et al. (2011) predicted shoreline change using the latest data of sea level rise in Japan, but the impacts on society were not taken into consideration. There are few studies which evaluate impacts of the future beach erosion on society by comparing with the past shoreline change resulting from natural forces and human activities. Objective of this study is to understand the longterm shoreline change due to natural forces and human activities in Japan.

\section{STUDY AREA AND METHODOLOGY}

The past century-scale shoreline changes in the cross-shore direction were investigated at Sendai, Niigata, Kashiwazaki, Kochi, and Miyazaki (Figure 1) in order to compare with each beach. These beaches have different physical features, such as grain size, beach slope, and wave height (Table 1). Wave characteristics were obtained by observation data. We obtained annual mean and maximum

\footnotetext{
${ }^{1}$ Department of Civil and Environmental Engineering, Tohoku University, Japan

${ }^{2}$ International Research Institute of Disaster Science, Tohoku University, Japan
} 
significant wave height from Nationwide Ocean Wave Information Network for Ports and Harbours (NOWPHAS), which observes real time mean and maximum significant wave height and period at the nearest observation points. Figure 2 shows recent beach topography in 2008 obtained by using laser scanning system by Geospatial Information Authority of Japan. Grain size was obtained using the relationship between foreshore slope and grain size described by beach erosion board (1961). This relationship indicates that foreshore slope becomes steeper, and grain size tends to be larger.

The century-scale shoreline changes in the cross-shore direction were obtained by adding the average backland boundary change to the beach width change. The beach width changes were obtained by dividing beach area by length of the shoreline. The beach areas and the length of the shoreline were extracted from 1/25000 scale old maps in around 1900, 1950, and 1990 (Kishida and Shimizu, 2000). In addition to these data, we extracted beach areas and length of shoreline from recent maps in around 2008. The rate of beach area and length of the shoreline was obtained by calculating with ArcGIS. The backland boundary changes in the cross-shore direction were caused by land-use changes between beach and backland due to change of beach to forest or residential area.

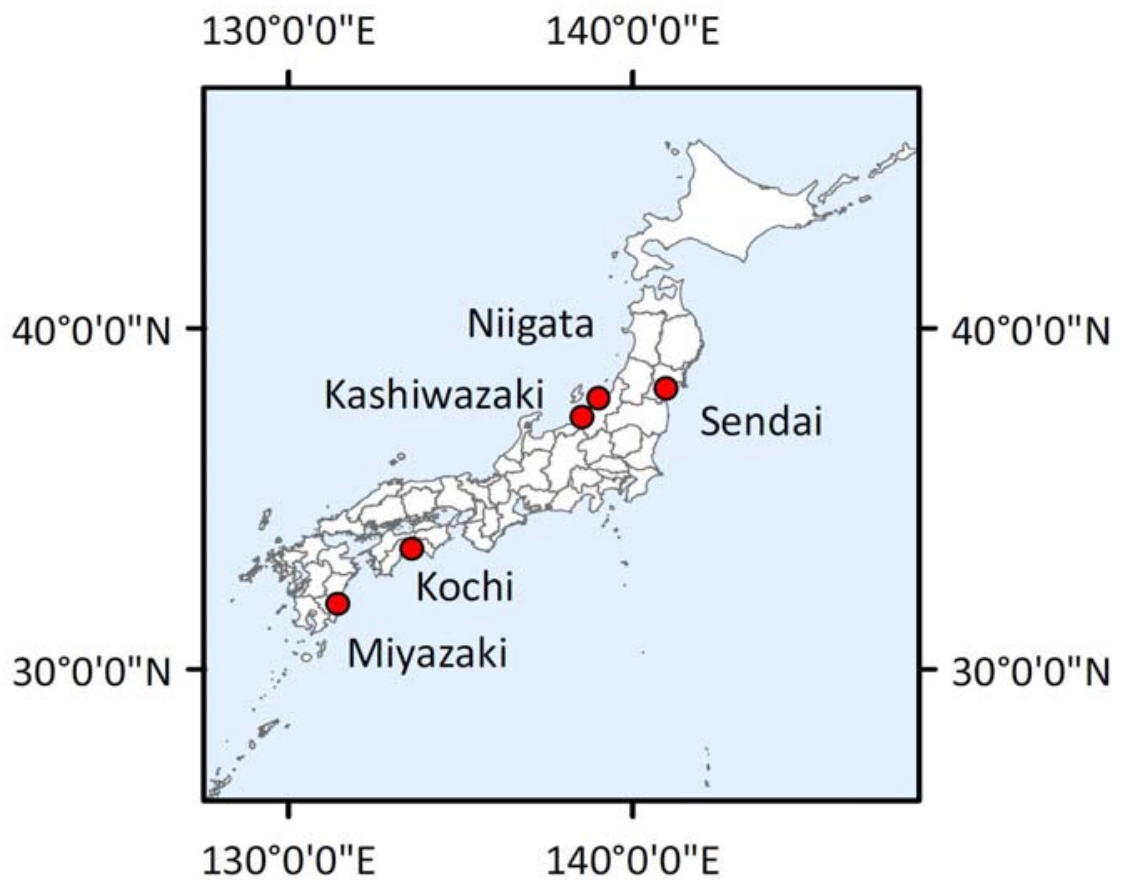

Figure 1. Location of five study areas

\begin{tabular}{|l|c|c|c|c|}
\hline \multicolumn{6}{|l|}{ Table 1. Physical beach features of five beaches in Japan } \\
\hline & $\begin{array}{c}\text { Grain Size } \\
(\mathrm{mm})\end{array}$ & Beach Slope & $\begin{array}{c}\text { Mean Significant } \\
\text { Wave Height }(\mathrm{m})\end{array}$ & $\begin{array}{c}\text { Maximum Significant } \\
\text { Wave Height }(\mathrm{m})\end{array}$ \\
\hline Sendai & 0.26 & 0.047 & 0.62 & 5.8 \\
\hline Niigata & 0.48 & 0.066 & 0.71 & 12.0 \\
\hline Kashiwazaki & 0.44 & 0.064 & 0.71 & 12.0 \\
\hline Kochi & 0.9 & 0.11 & 0.45 & 10.0 \\
\hline Miyazaki & 1.0 & 0.11 & 0.86 & 8.0 \\
\hline
\end{tabular}


(a)

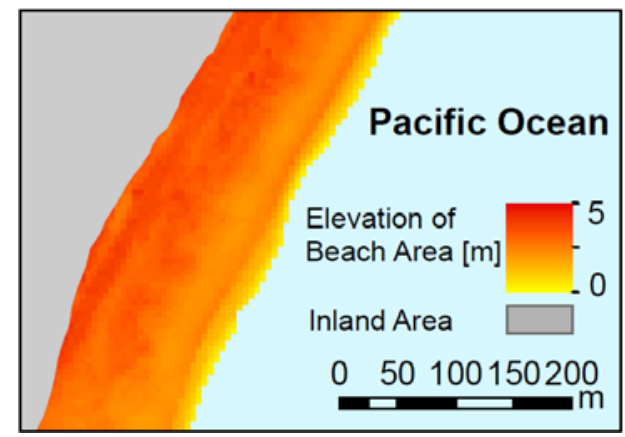

(c)

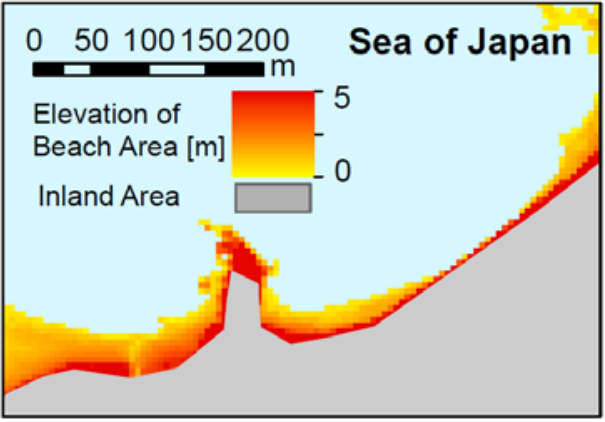

(b)

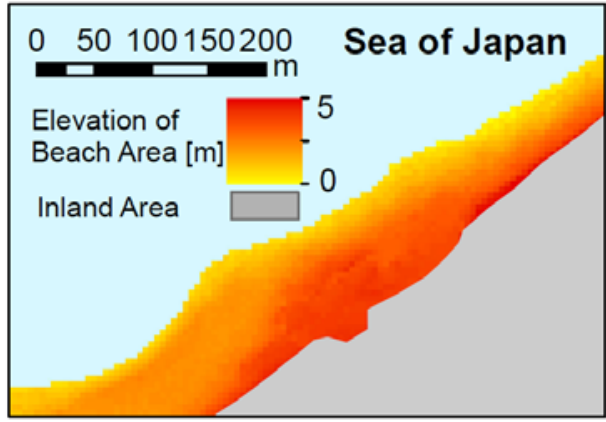

(d)

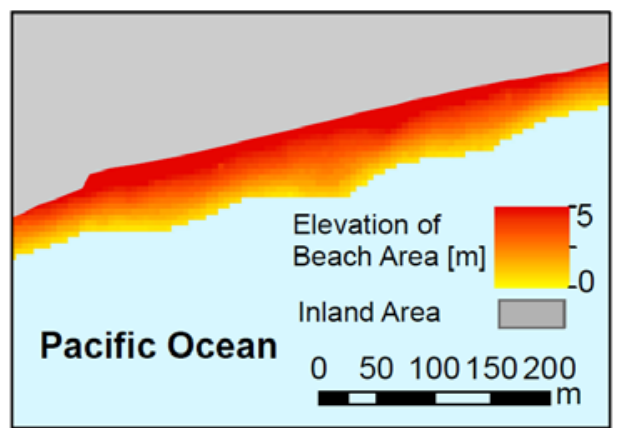

(e)

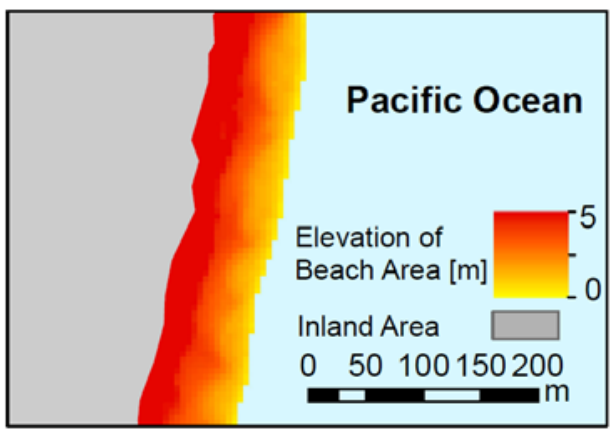

Figure 2. Beach topographies in around 2008 of (a) Sendai, (b) Niigata, (c) Kashiwazaki, (d) Kochi, and (e) Miyazaki

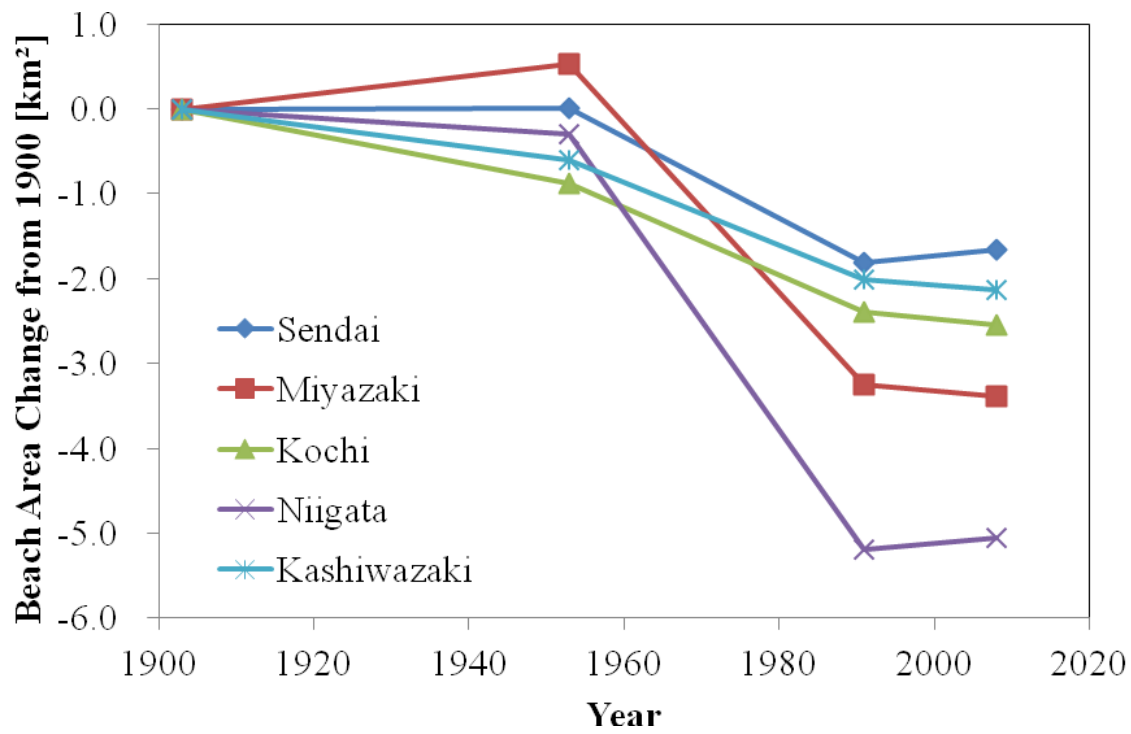

Figure 3. Beach area change from 1900 to 2008 of five Japanese beaches 


\begin{tabular}{|l|c|c|c|}
\hline \multicolumn{3}{|c|}{ Table 2. Rate of beach area changes of five beaches in Japan from 1900 to $\left.2008 \mathbf{~ ( k m}^{\mathbf{2}}\right)$} \\
\hline Sendai & $1900-1950$ & $1950-1990$ & $1990-2008$ \\
\hline Niigata & 0.0084 & -1.8 & -1.66 \\
\hline Kashiwazaki & -0.30 & -5.2 & -5.1 \\
\hline Kochi & -0.60 & -2.0 & -2.1 \\
\hline Miyazaki & -0.88 & -2.4 & -2.5 \\
\hline
\end{tabular}

\section{CHANGE OF FIVE BEACH AREAS}

Figure 3 shows the beach area changes of five beaches in Japan from 1900 to 2008. Table 2 shows the rate of beach area changes of five beaches in Japan from 1900 to 2008.

\section{Sendai}

Figure 4 shows the changes of Sendai beach area from 1900 to 2008. Sendai coast consists of sandy beach in the north and cliff coast in the south along the Pacific Ocean. Study area of Sendai beach extends for nearly $20 \mathrm{~km}$. The contour lines shallower than a depth of $30 \mathrm{~m}$ are nearly parallel to the shoreline, and bathymetry feature has uniformity in the direction to longshore. Sendai beach was formed by alleviation of Nanakitagawa River, Natorigawa River and Abukumagawa River. Natorigawa River is flowing into the study area, and the total amount of sediment supply from Natorigawa River between 1945 and 2002 is 1 million $\mathrm{m}^{3}$ (Ministry of Land, Infrastructure, Transport and Tourism, 2008). Wave direction dominates southeast. Direction of longshore sediment transport dominates north at Sendai beach. In the past, sea cliff erosion occurred at Fukushima coast located in the south of study area, and eroded sediment from the cliff coast was transported and deposited into Sendai beach; however, the rate of the sediment transport has decreased by cliff protection against erosion and breakwaters blocking the sediment transport.

Shoreline in the cross-shore direction changed within $10 \mathrm{~m}$ from 1900 to 1950 . Shoreline retreated about $65 \mathrm{~m}$ from 1950 to 1900. In this period, beach area especially in the north of Natorigawa River decreased and shoreline retreated because breakwaters at the Yriage Port blocked longshore sediment transport (Uda et al., 1990). Shoreline changed within $10 \mathrm{~m}$ from 1990 to 2008 because of countermeasures against beach erosion, such as the construction of detached breakwaters.

\section{Niigata}

Figure 5 shows the changes of Niigata beach area from 1900 to 2008. Study area of Niigata beach extends for nearly $35 \mathrm{~km}$ along the Sea of Japan (Figure 1). Niigata beach was formed by alleviation of Shinanogawa River. Niigata beach is one of the most eroded beaches because of the decrease of sediment supply from Shinanogawa River as a result of the construction of diversion aqueducts in 1922, and subsidence caused by pumping up of natural gas. Sekiya diversion aqueduct was in the west of Shinanogawa River, and delivered water in 1972. The total amount of sediment supply from this aqueduct between 1945 and 2002 is about 100 million $\mathrm{m}^{3}$, while the sediment supply from Shinanogawa River-decreased remarkably (Ministry of Land, Infrastructure, Transport and Tourism, 2008). Wave direction dominates northeast. Direction of longshore sediment transport dominates west. Near the mouth of Shinanogawa River, groins, seawall, detached breakwaters, and submerged breakwaters were constructed for the prevention of beach erosion.

Shoreline in the cross-shore direction changed within $10 \mathrm{~m}$ from 1900 to 1950. Shoreline retreated about $185 \mathrm{~m}$ from 1950 to 1990. In this period, beach area near the mouth of Shinanogawa River disappeared. Notable erosion occurred because of the decrease of sediment supply from Shinanogawa River and the disproportion of longshore sediment transport, that is, the amount of longshore sediment transport was lower than that of discharged sediment (Shinoda et al., 1992). Shoreline in the cross-shore direction changed within $10 \mathrm{~m}$ from 1990 to 2008. In this period, shoreline retreat was prevented by shore protection, such as groins, seawall, detached breakwaters, and submerged breakwaters.

\section{Kashiwazaki}

Figure 6 shows the changes of Kashiwazaki beach area from 1900 to 2008. Study area of Kashiwazaki beach extends for nearly $15 \mathrm{~km}$ along the Sea of Japan (Figure 1). Kashiwazaki beach was formed by alleviation of Sabaishigawa River and Ukawa River. The size of catchment area of two rivers was $312 \mathrm{~km}^{2}$ and $112 \mathrm{~km}^{2}$ respectively, and a few dams were constructed at the upper reaches of 

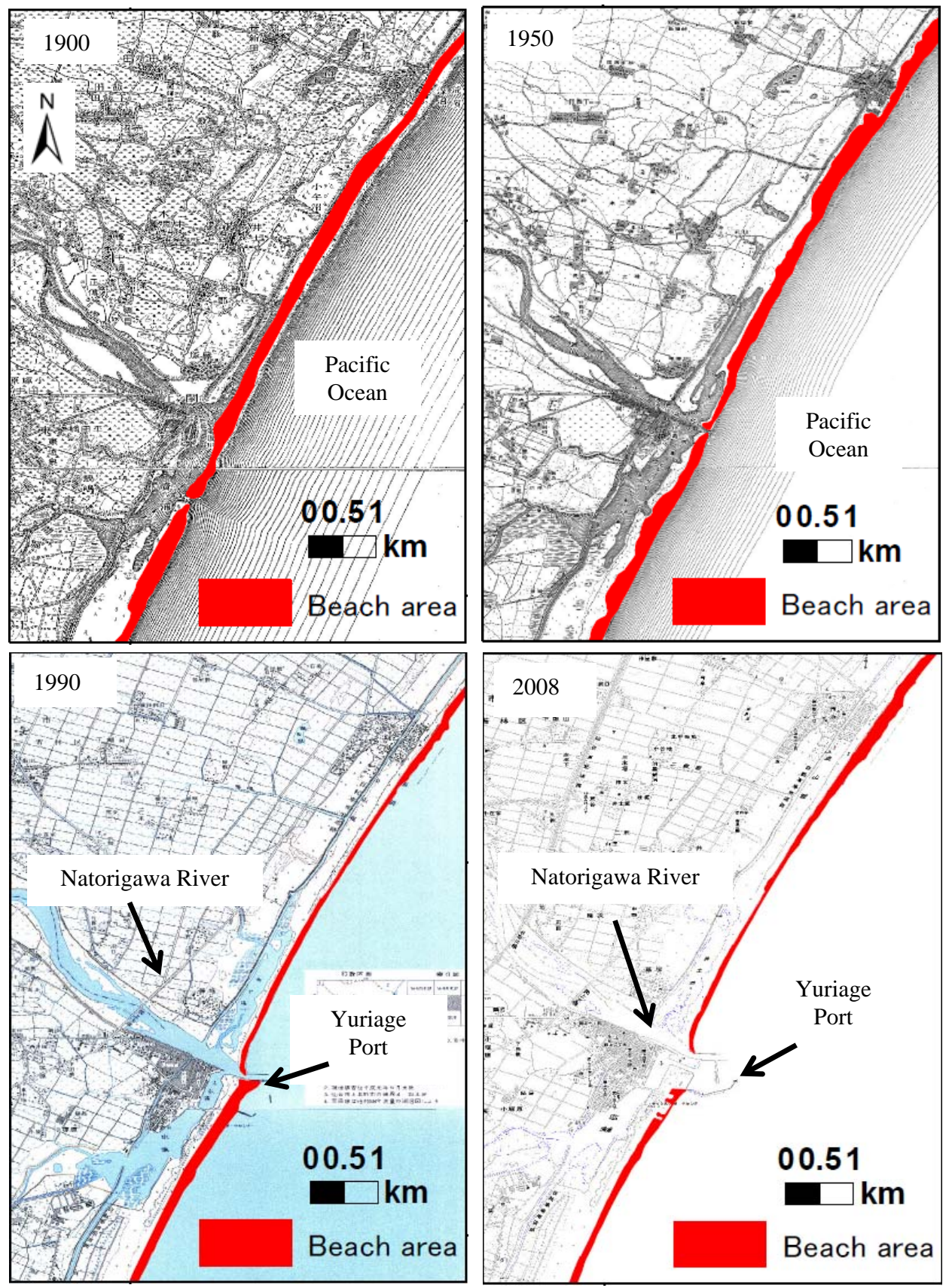

Figure 4. Change of Sendai beach area from 1900 to 2008

Sabaishigawa River, and the sediment supply from the river decreased. The total amount of sediment supply from two rivers between 1945 and 2002 is low (Ministry of Land, Infrastructure, Transport and Tourism, 2008). Wave direction dominates northeast. The Kashiwazaki Port located in the southern part of the beach is opened in 1971 and a few breakwaters placed around the port are about $2400 \mathrm{~m}$ long. The Kashiwazaki Karihane Nuclear Plant was located about 6 km northeast of the Kashiwazaki Port. Uda et al (1993) observed submarine elevation changes near the port to demonstrate characteristics of beach profile changes quantitatively. The observation resulted that the ground level near the Kashiwazaki Port rose, while the ground level near the Sabaishigawa River mouth dropped. Namely, waves were blocked by the breakwaters, and longshore sediment was deposited inside wave interrupted area. 

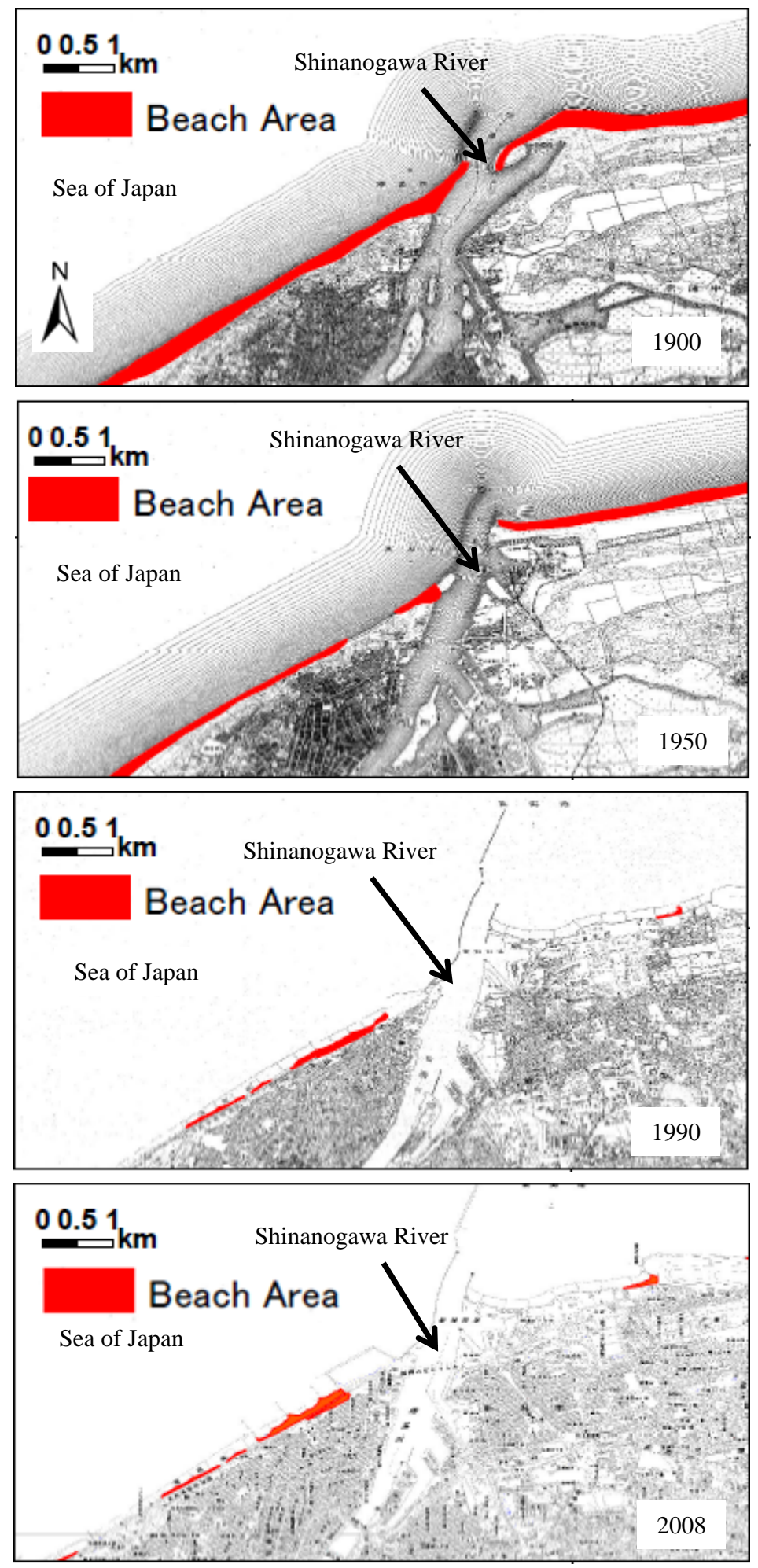

Figure 5. Change of Niigata beach area from 1900 to 2008

Shoreline in the cross-shore direction changed within $10 \mathrm{~m}$ from 1900 to 1950 . Shoreline retreated about $20 \mathrm{~m}$ from 1950 to 1990. Beach area disappeared because breakwaters at the Kashiwazaki Port blocked waves (Uda et al., 1993). Shoreline changed within $10 \mathrm{~m}$ from 1990 to 2008. 

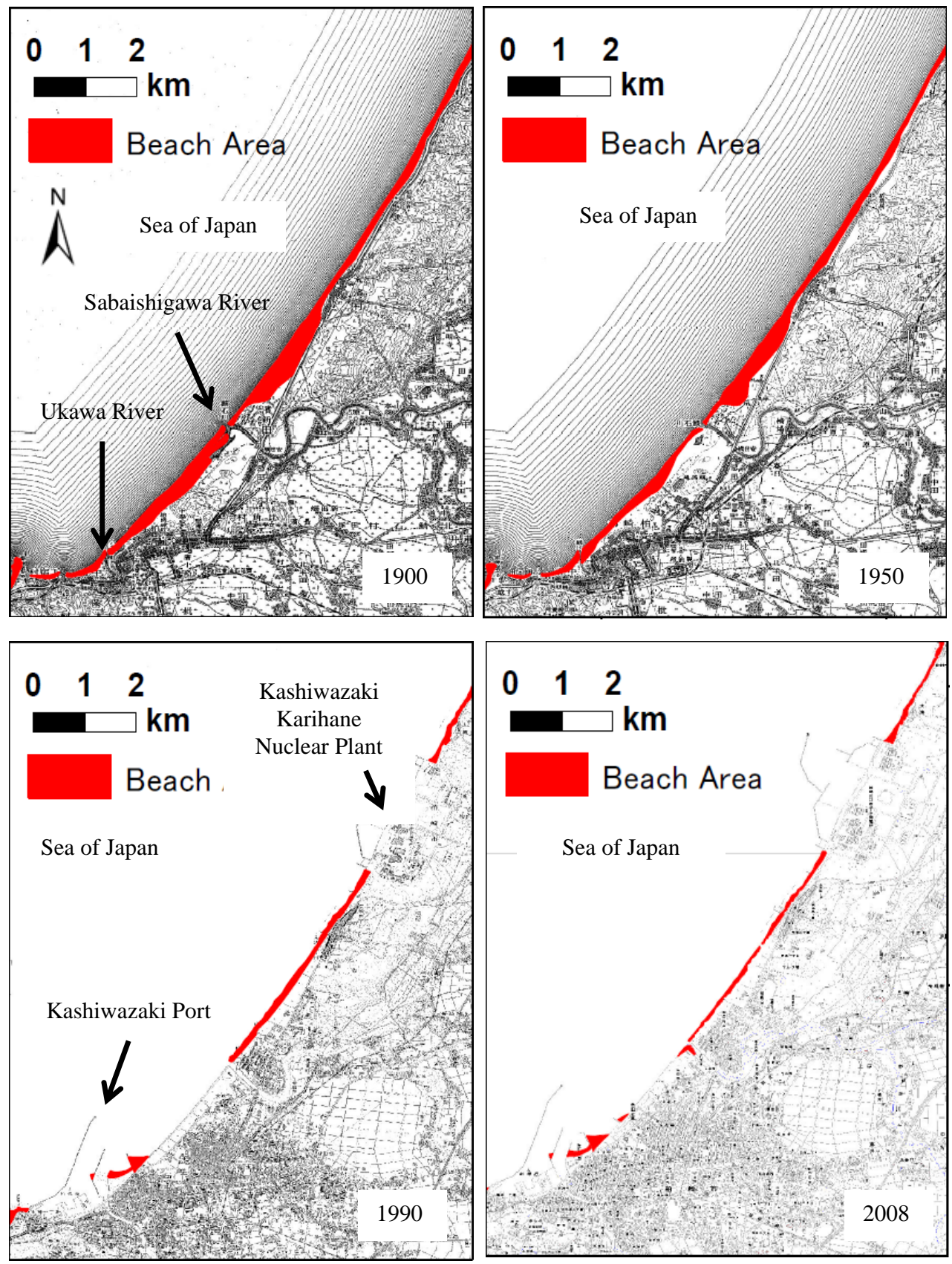

Figure 6. Change of Kashiwazaki beach area from 1900 to 2008

\section{Kochi}

Figure 7 shows the changes of Kochi beach area from 1900 to 2008. Study area of Kochi beach extends for nearly $30 \mathrm{~km}$ east and west along the Pacific Ocean (Figure 1). Kochi beach was formed by alleviation of Monobegawa River and Niyodogawa River. Monobegawa River is flowing into the study area. Three dams were built at the upper reaches of Monobe River. The total amount of sediment supply from this river between 1945 and 2002 is low (Ministry of Land, Infrastructure, Transport and Tourism, 2008). Sand near Monobegawa River was gathered, and the sand gathering led to its ban in 1974. Kochi beach is frequently damaged by typhoons, and tide wave height during typhoon is often more than $4 \mathrm{~m}$. Seawall and breakwaters were built in 1953 as one of the countermeasures in order to prevent coastal regions, as a result, reflected waves became higher. Many detached breakwaters were built at 50 meter intervals after around 1970. 


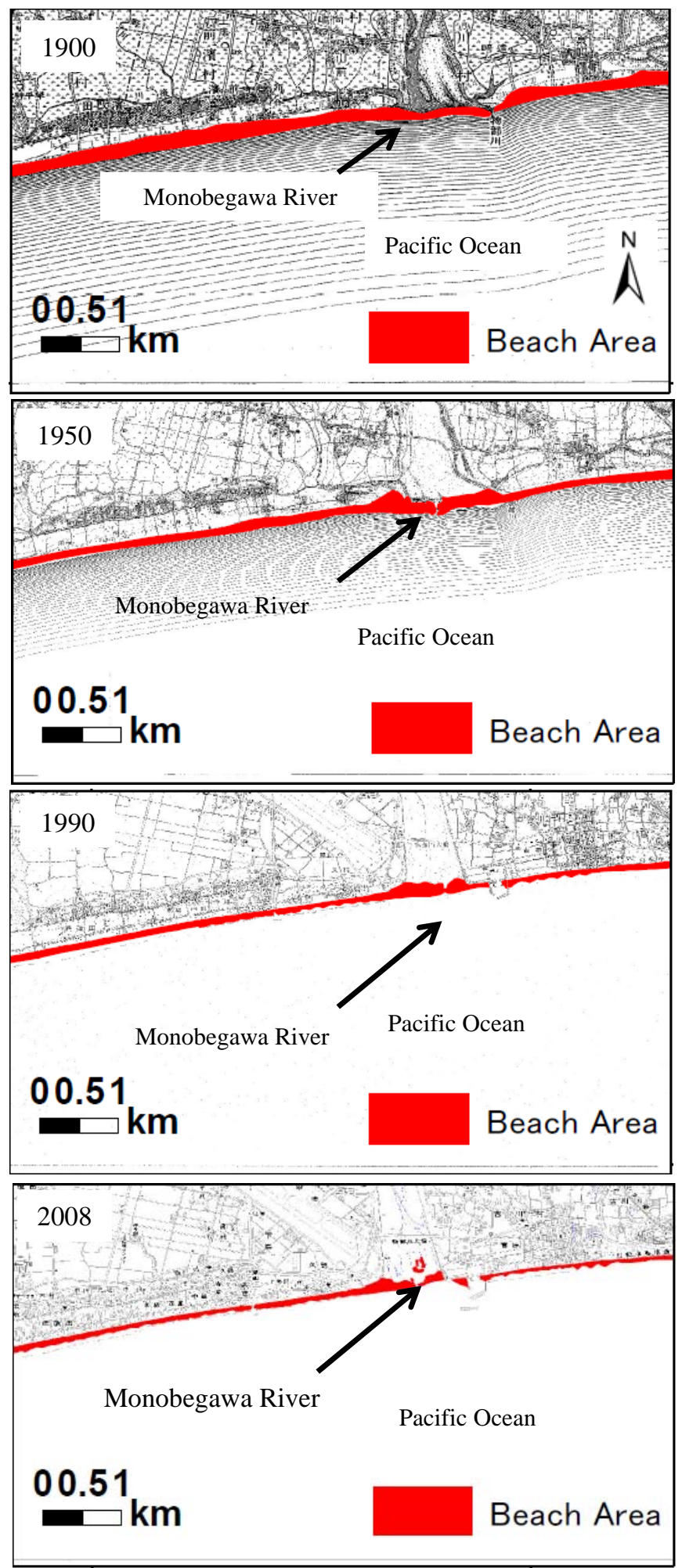

Figure 7. Change of Kochi beach area from 1900 to 2008

Shoreline in the cross-shore direction changed within $10 \mathrm{~m}$ from 1900 to 1950 . Shoreline retreated about $65 \mathrm{~m}$ from 1950 to 1990 . Beach erosion occurred because of the decrease of sediment supply from Monobegawa River caused by sand gathering and the construction of dams whose sedimentation sand rate is more than 15 \% (Agemori, 1977). Shoreline changed within $10 \mathrm{~m}$ from 1990 to 2008. 


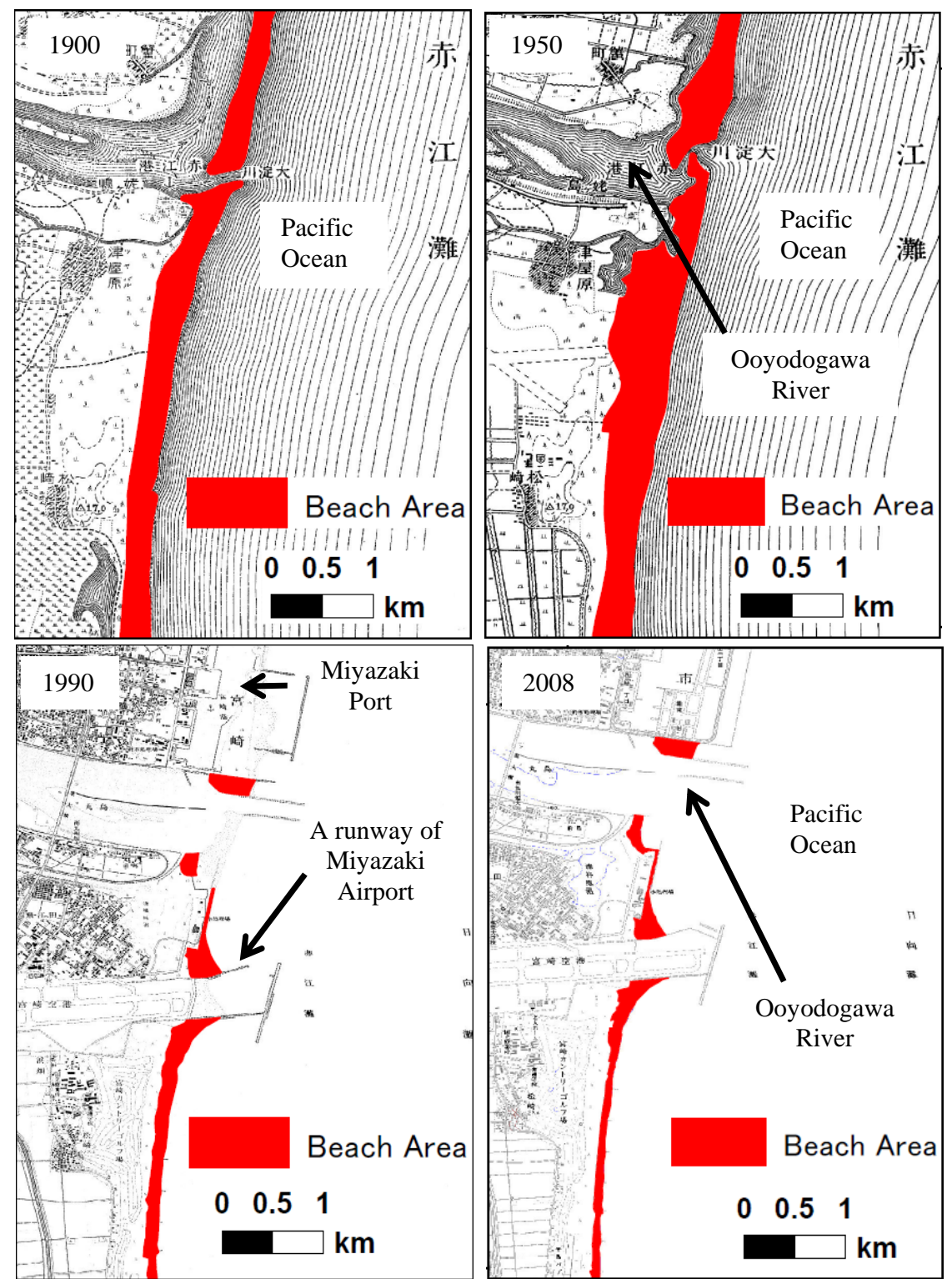

Figure 8. Change of Miyazaki beach area from 1900 to 2008

\section{Miyazaki}

Figure 8 shows the changes of Miyazaki beach area from 1900 to 2008. Study area of Miyazaki beach extends for nearly $16 \mathrm{~km}$ north and south along the Pacific Ocean (Figure 1). Miyazaki beach was formed by alleviation of Ooyodogawa River. The total amount of sediment supply from the river between 1945 and 2002 is 10 million $\mathrm{m}^{3}$ (Ministry of Land, Infrastructure, Transport and Tourism, 2008).Wind direction dominates east. Direction of longshore sediment transport dominates north at Miyazaki beach. The Miyazaki Port located in the northern part of the beach was opened in 1969 and a runway of the Miyazaki Airport located in the southern part of the beach jutted out into the sea in 1964 . Uda et al (1992) showed characteristics of beach profile changes by using bathymetry data from 1982 to 1990. The results showed that waves were blocked by the breakwaters at the Miyazaki Port and a runway of the Miyazaki Airport, and longshore sediment was deposited inside wave interrupted area.

Shoreline in the cross-shore direction migrated seaward about $30 \mathrm{~m}$ from 1900 to 1950. This migration was probably caused because of large amounts of sediment supply from Ooyodogawa River. Shoreline retreated about $90 \mathrm{~m}$ from 1950 to 1990. Beach erosion occurred because breakwaters at the Miyazaki Port and a runway of the Miyazaki Airport blocked longshore sediment transport (Uda et al., 1992). Shoreline changed within 10 m from 1990 to 2008. 


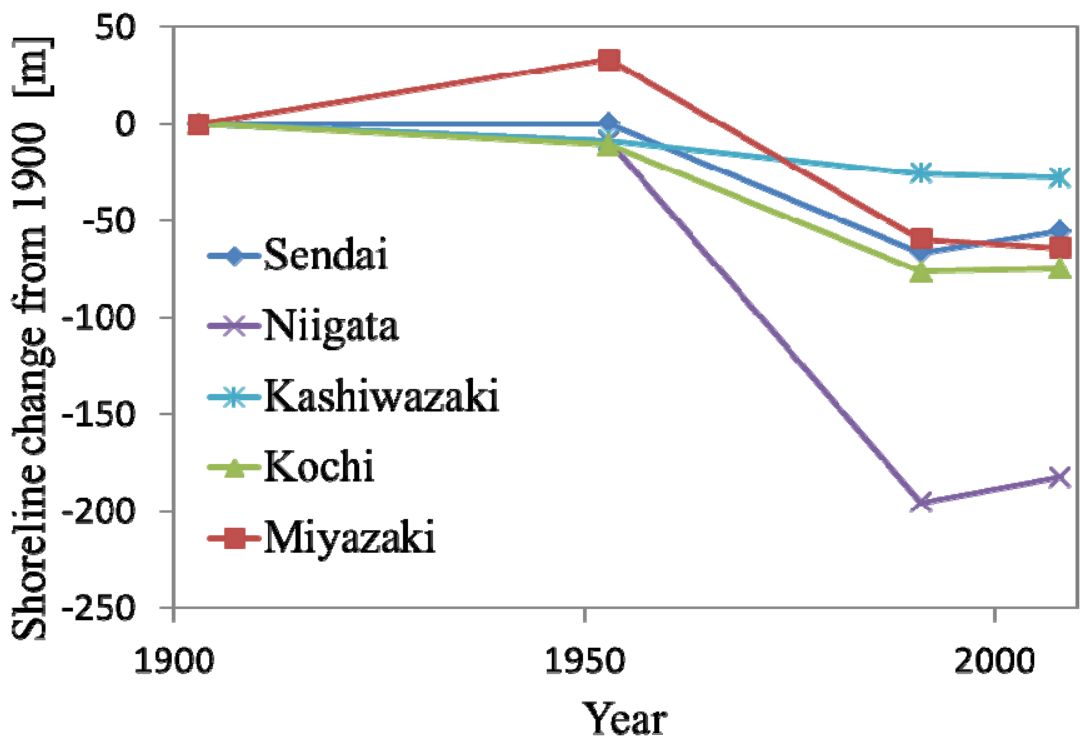

Figure 9. Past century-scale shoreline changes in the cross-shore direction of five beaches

\begin{tabular}{|c|c|c|c|}
\hline & $1900-1950$ & $1950-1990$ & $1990-2008$ \\
\hline Sendai & Within $10 \mathrm{~m}$ & Retreat $65 \mathrm{~m}$ & Within $10 \mathrm{~m}$ \\
\hline Niigata & Within $10 \mathrm{~m}$ & Retreat $185 \mathrm{~m}$ & Within10 m \\
\hline Kashiwazaki & Within $10 \mathrm{~m}$ & Retreat $20 \mathrm{~m}$ & Within10 $\mathrm{m}$ \\
\hline Kochi & Within $10 \mathrm{~m}$ & Retreat $65 \mathrm{~m}$ & Within10 m \\
\hline Miyazaki & Move seaward $30 \mathrm{~m}$ & Retreat $90 \mathrm{~m}$ & Within10 m \\
\hline
\end{tabular}

\section{CENTURY-SCALE SHORELINE CHANGES}

Figure 9 shows the past century-scale shoreline changes in the cross-shore direction summarizing five beaches. Table 3 shows the rate of shoreline changes in the cross-shore direction of five beaches in Japan.

From 1900 to 1950, shoreline in the cross-shore direction changed within $10 \mathrm{~m}$ at four study areas: Sendai, Niigata, Kashiwazaki, and Kochi. Shoreline migrated seaward at Miyazaki. Coastal structures, such as seawall, detached breakwaters, and groins, had not been built until Japanese Coast Act was enacted in 1956. Namely, Japan had not installed constructions against natural disasters, only repair work being done on damages caused by natural disasters in coastal zone. Thus, shoreline changes were influenced by natural forces in this period.

From 1950 to 1990, shoreline in the cross-shore direction retreated at all study areas, the rate of shoreline retreat was between 20 and $200 \mathrm{~m}$. Notable erosion was caused by the decrease of beach area as a result of the rapid coastal developments since the 1960's, the Japan's high-growth period after World War 2, and by the construction of coastal structures for disaster prevention. Thus, shoreline changes were influenced by human activities in this period.

From 1990 to 2008, shoreline in the cross-shore direction changed within $10 \mathrm{~m}$ at all study areas, and tended to be stable. Disaster prevention structures functioned appropriately against natural disasters. Japanese Coast Act was revised in 1999, and beach environment and utilization of beach by the public were included in the idea of coastal management in addition to disaster prevention. Accordingly, the rate of shoreline changes decreased compared with the rate of shoreline change from 1950 to 1990 . These results show that the current shoreline changes tend to be stable and that this trend is expected to continue. Coastal erosion due to climate change will likely become obvious in the future.

\section{CONCLUSION}

The past century-scale shoreline changes in the cross-shore direction were investigated at Sendai, Niigata, Kashiwazaki, Kochi, and Miyazaki. The century-scale shoreline changes in the cross-shore 
direction were obtained by adding the average backland boundary change to the beach width change. The beach width changes were obtained by dividing beach area by length of the shoreline. The beach areas and the length of the shoreline extracted from old maps in 1900, 1950, 1990, and 2008.

From 1900 to 1950, shoreline changes in the cross-shore direction were influenced by natural forces, because coastal structures had not been built until Japanese Coast Act was enacted in 1956. From 1950 to 1990, shoreline changes in the cross-shore direction were influenced by human activities, resulting from the rapid coastal development since the 1960's, the Japan's high-growth period after World War 2, and by the construction of coastal structure for disaster prevention. From 1990 to 2008, shoreline changes in the cross-shore direction tended to be stable because Japanese Coast Act was revised in 1999, and beach environment and utilization of beach by the public were included in the idea of coastal management in addition to disaster prevention.

\section{ACKNOWLEDGMENTS}

This study was supported in part by the Environment Research and Technology Development Fund (S-8) of the Ministry of the Environment, Japan. We express our deepest gratitude to Professor So Kazama of Tohoku University for valuable suggestions regarding how to treat the estimation data of climate change.

\section{REFERENCES}

Agemori, C. 1977. On the erosion and some disasters at the Kochi coast. Kochi University Digital Rep-ository for Academic resources. http://hdl.handle.net/10126/2321 (in Japanese)

Bruun, P.1962. Sea-level rise as a cause of shore erosion, J. Waterways and Harbors Div. ASCE, 88(WW1), pp. 117-130.

Intergovernmental Panel on Climate Change (IPCC): Climate Change 2007. The Scientific Basis. Contribution of Working Group I to the Fourth Assessment Report of the Intergovernmental Panel on Climate Change, edited by S. Solomon et al., Cambridge Univ. Press, New York., 2007.

Japan Meteorological Agency. 2008. Global Warming Projection Vol.7.

Keqi Zhang, Bruce C. Douglas and Stephen P. Leatherman. 2004. Global Warming and Coastal Erosion. Climatic Change. Vol. 64, Numbers 1-2, 41-58.

Kishida, H., and Shimizu, M. 2000. Extraction of coastal erosion and deposition through coastal information survey, Proceeding of Coastal Engineering, JSCE, Vol.47, 681-685. (in Japanese)

McGranahan DA, Balk D, Anderson B. 2007. The rising tide: assessing the risk of climate change and human settlements in low elevation coastal zones. Environ. Urban. 19:17-39

Ministry of Land, Infrastructure, Transport and Tourism. National Institute for Land and Infrastructure Management. 2008. TECHNICAL NOTE of National Institute for Land and Infrastructure Management No.445 23-24.

Mimura, N., Kiyohashi, M., and Inoue, K. 1993. Impacts of sea-level rise on sandy beaches, Proceeding of Coastal Engineering, JSCE, Vol.40, 1046-1050. (in Japanese).

Mimura, N., Inoue, K., Kiyohashi, S., Izumiya, T., and Nobuoka, H. 1994. Impact assessment of sea level rise on sandy beaches (2): Verification of validity of projection model and nationwide scale assessment. Proceeding of Coastal Engineering, JSCE, Vol.41, 1161-1165. (in Japanese)

Mori, N., Iwashima, R., Yasuda, T., Mase, H., and Tracey H. Tom. 2009. Projection of Global Winds and Waves under Global Warming Scenario Journal of Japan Society of Civil Engineers, Ser. B2 (Coastal Engineering) Vol. 65, No. 1, 1271-1275. (in Japanese)

Roshanka Ranasinghe and Marcel J. F. Stive. 2009. Rising seas and retreating coastlines. Climatic Change Vol. 97, Numbers 3-4, 465-468,

Shinoda, T., Uda,. T, and Okamura, Y. 1992. Proceeding of Coastal Engineering, JSCE, Vol.39, 346350. (in Japanese)

Sugawa T, Udo K, Mimura N, and Mano A. 2011. Journal of Japan Society of Civil Engineers, Ser. B2 (Coastal Engineering) Vol. 67, No. 2, 1196-1200. (in Japanese)

Uda, T., Omata, A. and Minematsu, M. 1990. Crisis of sandy beaches along Sendai Bay area, Proceeding of Coastal Engineering, JSCE, Vol.37, 479-483. (in Japanese)

Uda, T., and Noguchi, K. 1993. Beach changes caused by elongation of breakwater of Kashiwazaki Port, Proceeding of Coastal Engineering, JSCE, Vol.36, 229-244. (in Japanese) 